\title{
First record of Parapercis clathrata (Perciformes: Pinguipedidae) from Indian waters
}

\author{
K. KANNAN $^{1,3}$, K. PRABHU ${ }^{2}$, G. ARUMUGAM ${ }^{1}$ AND S. MOHAMED SATHAKKATHULLAH ${ }^{1}$ \\ ${ }^{1}$ TRC of Central Marine Fisheries Research Institute, Tuticorin, TamilNadu, India, ${ }^{2}$ CAS in Marine Biology, Faculty of Marine \\ Sciences, Annamalai University, TamilNadu, India, ${ }^{3}$ Wildlife Institute of India, Post Box \# 18, Chandrabani, Dehradun, \\ Uttarakhand, India
}

\begin{abstract}
A single specimen of latticed sandperch, Parapercis clathrata measuring $163 \mathrm{~mm}$ total lenth was caught in a trawler off Tuticorin, south-east coast of India in February 2010. Morphometric and meristic characters of the recorded specimen are described. This record constitutes the first occurrence of the species in Indian waters and a substantial westward extension of its known geographical distribution.
\end{abstract}

Keywords: Parapercis clathrata, Pinguipedidae, latticed sand perch, Indian Ocean and Tuticorin

Submitted 28 August 2011; accepted 16 January 2012

\section{INTRODUCTION}

The perciform sandperch family Pinguipedidae was formally known as the Parapercidae or Mugiloididae (Rosa \& Rosa, 1987; Randall, 2001). The family includes 79 species in seven genera, Pinguipes, Parapercis, Prolatilus, Pseudopercis, Kochichthys, Simipercis and Ryukyupercis (Ho \& Shao, 2010). The genus Parapercis was described by Bleeker, 1863. It is the largest genus in the family, currently comprising 71 valid species (Johnson, 2006; Randall \& Yamakawa, 2006; Randall, 2008; Randall et al., 2008; Ho \& Shao, 2010). The fish of the genus Parapercis are popularly known as sandperch in the United States, grubfish in Australia and sandsmelt in South Africa. From the central and western Pacific 22 species of Parapercis have been recorded (Randall, 2001). Twenty-seven species including four new species have been recorded from Japan (Shimada, 2002; Randall \& Yamakawa, 2006; Randall, 2008; Randall et al. 2008). Ho \& Shao (2010) described one new species from Taiwan. Recently one new species has been reported from western Pacific waters (Yun Chio Liao et al., 2011). More numbers of new species discovered in the genus clearly shows the dearth of up to date information in the literature.

The sandperch family Pinguipedidae comprises seven genera and 78 valid species. Sixteen new species of Parapercis have been described in the past five years (Johnson, 2006; Randall \& Yamakawa, 2006; Imamura \& Yoshino, 2007; Randall, 2008; Randall et al., 2008); P. clathrata grows up to a total length (TL) of $24 \mathrm{~cm}$ (Kuiter \& Tonozuka, 2001). The species occurs in tropical marine waters of the Indo-Pacific from the Andaman Sea north to Japan, throughout Micronesia, south to Australia and east to the Samoa

Corresponding author:

K. Kannan

Email: kanna.k84@gmail.com
Islands (Randall, 2001). It inhabits both clear lagoon and seaward reefs, in the areas of open sand, rubble as well as on the rocky surfaces between coral heads of $3 \mathrm{~m}$ to $50 \mathrm{~m}$ (Myers, 1991).

\section{RESULTS}

On 14 February 2010, a $163 \mathrm{~mm}$ TL male $P$. clathrata (Figure 1) weighing $50 \mathrm{~g}$ was collected from a commercial trawler, which operated at a depth $30 \mathrm{~m}, 60 \mathrm{~km}$ north-west off Tuticorin, south-east coast of India. All the counts and morphometric measurements were taken according to Masuda et al. (1984).

\section{Description}

The body is moderately elongated and little compressed, except posteriorly. The head is pointed and tapered on the tip. The tip of the snout is flat with large eyes, slightly prominent above the dorsal profile of the head, oriented as much dorsally as laterally. Mouth is large and terminal with lower jaw slightly projecting having recurved canine teeth in an outer row at front of the jaws. The lateral line is simple and complete having 60 pored scales. The dorsal fin has IV spines and 20 soft rays, anal fin with I spine and 17 soft rays, pelvic fin has I spine and 4 soft rays; pectoral fins with 17 soft rays. Gill rakers on the first gill arch range from 17 to 19. The colour of the dorsal surface is reddish-brown, belly whitish, head with brown patches, cheeks with many small black spots and prominent eye spots on the nape (typical of males: Randall et al., 1990; Myers, 1991). Lower side of the body has 12 vertically elongate spots; each spot is black in colour. Two narrow horizontal lines run from the pectoral fin origin, to the caudal fin base. Pectoral and pelvic fins are dusky yellow and posterior half of caudal fin 

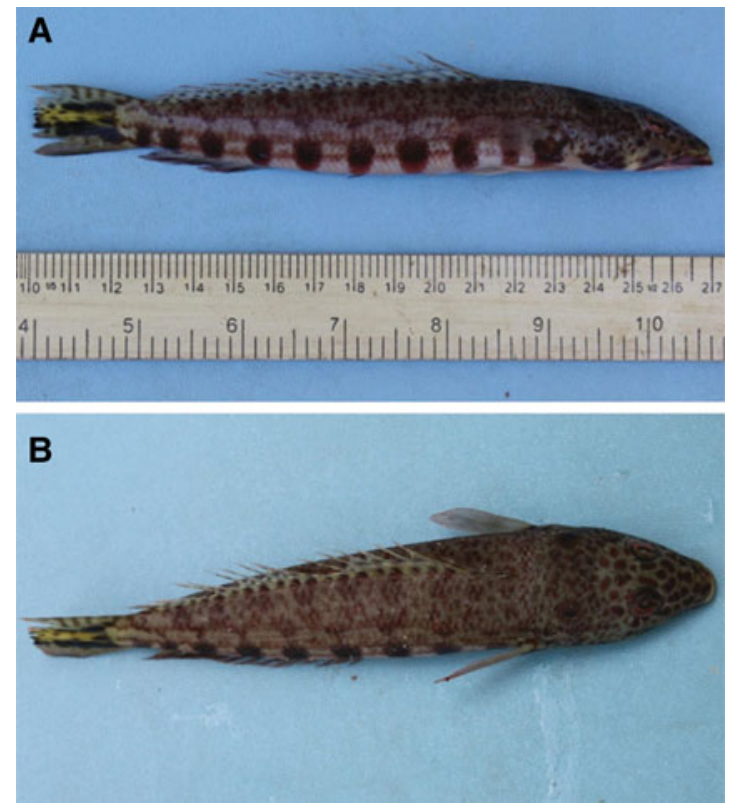

Fig. 1. Parapercis clathrata caught off Tuticorin, south-east coast of India: (A) lateral view; (B) dorsal view.

has a large yellow spot, having small brown spots within. Caudal fin is truncate. All counts and measurements are shown in Table 1.

The morphological characters of the studied specimen agree with the diagnostic features proposed by Randall (2001) to discriminate $P$. clathrata from other central-western Pacific species of the genus. According to Randall (2001), the number of spines and soft rays in the dorsal and anal fins discriminate $P$. clathrata and $P$. millepunctata from other species of Parapercis in this area. Whereas, by contrast, gill raker counts and differences in the coloration of the anal fin separate $P$. clathrata from P. millepunctata.

Table 1. The morphometric characters of Parapercis clathrata caught off Tuticorin.

\begin{tabular}{lc}
\hline Morphometric characters & Measurements (mm) \\
\hline Total length & 163 \\
Standard length & 145 \\
Head length & 43 \\
Head width & 17 \\
Body width & 30 \\
Pre-orbital length & 15 \\
Post-orbital length & 20 \\
Orbital eye diameter & 10 \\
Lower jaw length & 14 \\
Upper jaw length & 17 \\
Dorsal fin length & 16 \\
Dorsal fin base length & 88 \\
Pre-dorsal fin length & 50 \\
Pectoral fin length & 26 \\
Pectoral fin base length & 7 \\
Pre-pelvic fin length & 31 \\
Pelvic fin length & 30 \\
Pelvic fin base length & 1.2 \\
Pre-anal length & 67 \\
Anal fin length & 20 \\
Anal fin base length & 65 \\
Caudal peduncle length & 43.9 \\
\hline
\end{tabular}

\section{DISCUSSION}

During recent years, greater numbers of fish species have been recorded for the first time in Indian waters (see Akhilesh et al., 2009; Kurup et al., 2009). Although some of these are probably residents in these areas that might have remained undetected due to intrinsic rarity or difficulty of access to these specific habitats (e.g. deep sea), some others can be considered 'vagrant' (i.e. they have arrived from the other areas). Parapercis clathrata is a reef-associated (Meyers, 1991; Kuiter \& Tonozuka, 2001) benthic fish; the location from which the specimen is captured is also close to a major coral reef off the southern Indian main land-Gulf of Mannar. At this juncture there is much uncertainty about the presence of $P$. clathrata in Indian waters. More detailed monitoring of fish diversity in the Andaman and Nicobar Islands, the eastward territorial waters of India may spread some light on the westward range extension of this species towards more conducive habitats of the tropical Indian Ocean. For whatever reasons, recent records of this species from a new geographical area are a matter of scientific interest and solicit the need for more comprehensive investigation.

\section{ACKNOWLEDGEMENTS}

The authors are grateful to Dr K.K. Joshi, Senior Scientist and P.U. Zacharia, HOD of DFT \& Senior Scientist, Central Marine Fisheries Research Institute, Cochin, for offering valuable suggestions, the anonymous referees for their valuable comments and Mr Sajan John (Dakshin Foundation) for suggestions on the manuscript.

\section{REFERENCES}

Akhilesh K.V., Pillai N.G.K., Ganga U., Bineesh K.K., Rajool Shanis C.P. and Manjebrayakath H. (2009) First record of the anthiine fish, Meganthias filiferus (Perciformes: Serranidae) from Indian waters. Marine Biodiversity Records 2, e113. DOI: 10.1017/ S1755267209001201. Published online.

Bleeker P. (1863) Onzième notice sur la faune ichthyologique de l'île de Ternate. Nederlandsch Tijdschrift voor de Dierkunde 1, 228-238.

Ho H.C. and Shao K.T. (2010) Parapercis randalli, a new sandperch (Pisces: Pinguipedidae) from southern Taiwan. Zootaxa 2690, 59-67.

Imamura H. and Yoshino T. (2007) Three new species of the genus Parapercis from the western Pacific, with redescription of Parapercis hexophtalma (Perciformes: Pinguipedidae). Bulletin of the National Museum of Nature and Science, Series A Supplement 1, 81-10o.

Johnson J.W. (2006) Two new species of Parapercis (Perciformes: Pinguipedidae) from north-eastern Australia, and rediscovery of Parapercis colemani Randall \& Francis, 1993. Memoirs of the Museum of Victoria 63, 47-56.

Kuiter R.H. and Tonozuka T. (2001) Pictorial guide to Indonesian reef fishes. Part 2. Fusiliers-Dragonets, Caesionidae-Callionymidae. Melbourne, VIC: Zoonetics, pp. 304-622.

Kurup B.M., Cubelio S.S., Joseph G., Venu S. and Deepu A.V. (2009) First record and redescription of Glyptophidium oceanium (Ophidiiformes: Ophidiidae) from the Indian Ocean. Marine Biodiversity Records 2, e42. DOI: 10.1017/S1755267209000402. 
Masuda H., Amaoka K., Araga C., Uyeno T. and Yoshino T. (1984) The fishes of the Japanese Archipelago. Volume 1. Tokyo: Tokai University Press, 437 pp., 370 pls.

Myers R.F. (1991) Micronesian reef fishes. 2nd edition. Barrigada, Guam: Coral Graphics, 298 pp.

Randall J.E. (2001) Pinguipedidae. In Carpenter K.E. and Niem V.H. (eds) FAO Species identification guide for fishery purposes. The living marine resources of the western central Pacific. Volume 6. Bony fishes, part 4 (Labridae to Latimeriidae), estuarine crocodiles, sea turtles, sea snakes and marine mammals. Rome: FAO, pp. 3501-3510.

Randall J.E. (2008) Six new sandperches of the genus Parapercis from the western Pacific, with description of a neotype for P. maculata (Bloch \& Schneider). Raffles Bulletin of Zoology Supplement 19, 159-178.

Randall J.E., Allen G.R. and Steene R.C. (1990) Fishes of the Great Barrier Reef and Coral Sea. Honolulu, Hawaii: University of Hawaii Press, $506 \mathrm{pp}$.

Randall J.E. and Yamakawa T. (2006) Parapercis phenax from Japan and $P$. banoni from the southeast Atlantic, new species of pinguipedid fishes previously identified as P. roseoviridis. Zoological Studies 45, $1-10$.
Randall J.E., Senou H. and Yoshino T. (2008) Three new pinguipedid fishes of the genus Parapercis from Japan. Bulletin of the National Museum of Nature and Science, Series A Supplement 2, 69-84.

Rosa I.L. and Rosa R.S. (1987) Pinguides Cuvier and Valenciennes and Pinguipedidae Günther, the valid names for the fish taxa usually known as Mugiloides and Mugiloididae. Copeia 1987, 1048-1051.

Shimada K. (2002) Pinguipedidae. In Nakabo T. (eds) Fishes of Japan with pictorial keys to the species. English edition. Tokyo: Tokai University Press, pp. 1059-1064, 1586-1587.

and

Yun-Chih Liao., Tun-Yuan Cheng and Kwang-Tsao Shao (2011) Parapercis lutevittata, a new cryptic species of Parapercis (Teleostei: Pinguipedidae), from the western Pacific based on morphological evidence and DNA barcoding. Zootaxa 2867, 32-42.

\section{Correspondence should be addressed to:}

K. Kannan

Wildlife Institute of India,

Post Box \# 18, Chandrabani, Dehradun

Uttarakhand, India

email: kanna.k84@gmail.com 